ISSN 0103-5150

Fisioter. Mov., Curitiba, v. 24, n. 2, p. 327-335, abr./jun. 2011 Licenciado sob uma Licença Creative Commons

\title{
Physical therapy treatment in incontinent women provided by a Public Health Service
}

\author{
Fisioterapia em mulheres incontinentes atendidas em um serviço \\ público de saúde
}

\author{
Daniela D’Attilio Toledo ${ }^{[a]}$, Anny Caroline Dedicação ${ }^{[b]}$, Maria Elisabete Salina Saldanha ${ }^{[c]}$, \\ Miriam Haddad $^{[\mathrm{d}]}$, Patricia Driusso ${ }^{[\mathrm{e}]}$ \\ [a] Specialist in Integrated Physiotherapy in Women's Health at Universidade de São Paulo (USP), São Paulo, SP - Brazil. \\ [b] Enhancement in Integrated Physiotherapy in Women's Health at Maternidade Hospital Leonor Mendes de Barros, São \\ Paulo, SP - Brazil. \\ [c] Master in Morphology at Federal University of São Paulo, professor of the Physiotherapy course at Universidade de São \\ Paulo, São Paulo, SP - Brazil. \\ [d] Gynecologist at Maternidade Hospital Leonor Mendes de Barros São Paulo, SP - Brazil. \\ [e] PhD in Sciences at Federal University of São Carlos, professor of Physiotherapy course at Universidade Federal de São \\ Carlos, São Carlos, SP - Brazil, e-mail: pdriusso@ufscar.br
}

\begin{abstract}
Introduction: Urinary incontinence affects more than 50 million people worldwide, it has a great impact on quality of life by affecting social, domestic, occupational and sex life, regardless of age. Objective: The objective of this study was to analyze the effectiveness of physical therapy treatment in women attending the Urogynecology service of Hospital and Maternity Leonor Mendes de Barros. Method: We retrospectively assessed 65 records of patients with diagnosis of urinary incontinence treated between November 2005 and November 2006. In order to have their data analyzed, patients were divided into two groups; group MF, which underwent medical treatment and physiotherapy, and group $\mathrm{M}$, which had only medical treatment. In order to compare both groups' quantitative data, the analysis was performed in Statistica ${ }^{\circledR}$ software using Mann Whitney's non-parametric test. The analysis of association between the quantitative variables was performed through the Chi-Square test at $5 \%(\mathrm{p} \geq 0.05)$ significance level. Results: We observed that $60.6 \%$ of patients who underwent physical therapy treatment and medical treatment had the urinary incontinence symptoms decreased or completely cured, while $80 \%$ of women belonging to the medical treatment
\end{abstract}


only-group underwent surgery. Conclusion: Thus, we conclude that physical therapy is essential in treatment protocols of urinary incontinence outpatient clinics and to prevent surgery.

Keywords: Urinary incontinence. Physical therapy treatment. Surgery.

\section{Resumo}

Introdução: A incontinência urinária afeta mais de 50 milhões de pessoas em todo o mundo, apresenta um grande impacto na qualidade de vida, afetando a vida social, doméstica, profissional e sexual, independente da idade. Objetivo: $O$ objetivo deste estudo foi analisar a eficácia do tratamento fisioterapêutico em mulheres atendidas pelo serviço de Uroginecologia do Hospital e Maternidade Leonor Mendes de Barros. Método: Foram avaliadas retrospectivamente 65 prontuários de pacientes com diagnóstico de incontinência urinária atendidos entre novembro 2005 e novembro de 2006. A fim de ter seus dados analisados, as pacientes foram divididos em dois grupos: grupo MF, formado por pacientes submetidas a tratamento médico e fisioterapêutico e grupo $M$, que submeterem-se à tratamento médico. A análise foi realizada no programa Statistica ${ }^{\circledR}$, por meio de teste não paramétrico de Mainn Withney, para a comparação dos dados quantitativos entre os dois grupos. Para a análise da associação entre as variáveis quantitativas foi utilizado o teste Qui-Quadrado, adotando-se nível de significância de 5\% ( $p \geq 0$,05). Resultados: Observou-se que 60,6\% das pacientes que realizaram o tratamento fisioterapêutico em associação ao tratamento médico obtiveram diminuição ou melhora total dos sintomas da incontinência urinária. Enquanto que $80 \%$ das mulheres do grupo que realizou tratamento médico foram submetidas à intervenção cirúrgica. Conclusão: Portanto, concluí-se que o tratamento fisioterapêutico é parte importante nos protocolos de tratamentos nos ambulatórios de Incontinência Urinária e medida preventiva para intervenção cirúrgica.

Palavras-chave: Incontinência urinária. Fisioterapia. Cirurgia.

\section{Introduction}

The International Continence Society (ICS) had recently defined Urinary Incontinence (UI) as "any involuntary loss of urine" (1). UI can be classified according to its symptoms, clinical findings and additional examinations, as: Stress Urinary Incontinence (SUI), Overactive Bladder (OB) or Mixed Urinary Incontinence (MUI) (2).

The SUI is characterized by involuntary urine loss, when intravesical pressure exceeds the maximum urethral pressure in the absence of detrusor urinae muscle contraction. It usually happens when the person coughs, sneezes, laughs, jumps or even performs activities such as changing body position $(3,4)$. The $\mathrm{OB}$ is characterized by involuntary urine loss while feeling strong desire to urinate, whether the bladder is full or not, and is associated with increased urinary frequency, nocturia and urge incontinence. The symptoms are usually caused by involuntary detrusor urinae muscle contractions $(5,6)$. The MUI is characterized by the symptoms of both incontinence types described above (7).
Urinary incontinence affects more than 50 million people worldwide, from which 13 million are in the USA $(8,9)$. It is a common problem affecting women of all ages. Epidemiological studies performed in young adults show a prevalence varying between 30 and 55\% (10). Institutionalized elderly women are the most affected by UI, whose prevalence progressively increases with age $(8,11$, 12 ). From those women affected, $30 \%$ were below 60 years old, and $41-57 \%$ were over 65 years old $(13,14) ; 20-35 \%$ lived in communities and $30-60 \%$ were institutionalized $(8,15,16)$.

Urinary incontinence substantially impairs one's quality of life (QL) by affecting social, domestic, occupational and sex life, regardless of age. According to Monz et al. (17) and Ghoniem et al. (18), the more severe symptoms are, the more they affect the QL. Shame prevents patients from seeking medical care and restricts their social lives, thus leading them to isolation.

Medical care is carefully evaluated and prescribed by physicians due to its side effects. OB is the UI type with greater response to medical care, allowing the 
use of anticholinergics, alpha-agonists and tricyclic antidepressants. The latter is the most recommended, as it provides better results and fewer side effects $(19,20)$. The use of sacral neuromodulators and minimally invasive intervention stand out among surgical interventions, as these practices were approved by the Food and Drug Administration (FDA), in 2002, to be employed in overactive bladder (21) treatment. Surgical options to treat SUI may include abdominal and vaginal procedures, laparoscope and related practices (22).

The physical therapy treatment is aimed at restoring patients' continence and improving their quality of life. There are several physiotherapy options for incontinent patients: kinesiotherapy, biofeedback, vaginal cone and electropathy. According to Aslan et al. (23), such results decrease urinary loss from 30 to $50 \%$ within a twelve-month period. The proper contraction of the pelvic floor (PF) muscles, especially the levator ani muscle, has been an efficient way to treat patients with UI and improve their toilet training $(24,25)$.

Biofeedback is a therapeutic resource efficiently used to treat women with UI by itself or together with other therapies (26). By means of audible or visual biofeedback, the patient acquires information on the physiological process of contraction, which was unknown in most cases until then (27). Aukee et al. (28) observed significant improvement in the strengthening of the PF muscle in women with UI who had undergone biofeedback and kinesiotherapy treatment, within a twelve-year period. Morkved e Fjortoft (29) compared women with SUI who had performed PF functional training exercises with women who had been trained with biofeedback, and observed 58\% improvement in women who had used biofeedback and $46 \%$ in those who had only exercised. Aksac et al. (30) also studied the effects of perennial exercise and biofeedback, and observed improved strength in both groups; however, there was greater gain in the group trained with biofeedback.

Electro stimulation can be performed through percutaneous, intravaginal or intrarectal application (31). The intracavitary way activates the afferent pudendal nerve, thus facilitating efferent response and causing the contraction of smooth and striated muscles in the paraurethral and PF region. The percutaneous application through the sacral roots or posterior tibial nerve act in the neuromodulation of the detrusor urinae muscle (32) activities, providing $60 \%$ general improvement in symptoms and significant statistical decrease in loss, number of absorbents used, frequency and nocturia (33). Although ES had been proved to be an useful therapeutic alternative for women with SUI, by achieving a $82.34 \%$ improvement rate $(34,35)$, its better results were achieved in patients with $\mathrm{OB}(32,35,36)$. A frequency between 35 and $50 \mathrm{~Hz}$ (34) is used for the SUI treatment, while the OB treatment requires a frequency between 5 and $20 \mathrm{~Hz}$ (37).

The objective of this study was to verify the effectiveness of physical therapy in treating urinary incontinence, considering the muscular strength of pelvic floor, urinary frequency, nocturia and continence.

\section{Materials and methods}

We performed a retrospective study of patients who underwent medical treatment for urinary incontinence at the Urogynecology Sector of Hospital Maternity Leonor Mendes de Barros, between November 2005 and November 2006. Patients were selected by means of an urodynamic examination registration program and were divided into two groups; from which one was going to undergo physical therapy (MF) while the other not (M).

During this period, 89 women had undergone the urodynamic examination. Patients with neurological diseases, diabetic neuropathy, congenital urologic disease, bladder cancer and neurogenic bladder were excluded from the study.

Thus, 72 patients were contacted by telephone and/or at the hospital's Urogynecology Sector (annual gynecological follow-up and/or participation in treatment groups) and were informed on the characteristics of the project (15 had changed their phone numbers and one had died). 65 women agreed to make their data available for this research and signed a Free and Clarified Consent Term, according to resolution 196/96 of the National Health Council. The research was approved by the Ethics Committee of Maternity Hospital Leonor Mendes de Barros, according to Opinion No. 13198462.

The group MF ( $\mathrm{n}=33$ ) was comprised of patients who underwent physical therapy, regardless of the treatment performed (technique and number of sessions), simultaneously to the medical treatment. Group M ( $\mathrm{n}=32)$ was comprised of women 
sent to physical therapy treatment by the medical staff, but who did not attend the sessions whether for the lack of scheduling, time or money. In order to compare both groups' quantitative data, the analysis was performed in the Statistica ${ }^{\circledR}$ software using Mann Whitney's non-parametric test. The analysis of association between the quantitative variables was performed through the Chi-Square test at 5\% ( $p \geq 0.05$ ) significance level.

\section{Results}

The average age of volunteers taking part in this study was $50.51 \pm 10.63$. Women from the group that underwent physical therapy treatment had an average age of $53.68 \pm 10.08$ (37-77) years, while the average age of women comprising the group who did not take physiotherapy was of $47 \pm 10.27$ years $(\mathrm{p}=0.06)$.

Table 1 shows the characterization of both groups based on the urinary incontinence diagnosis. One can notice the prevalence of SUI, followed by OB and MUI in both groups. According to the Chi-Square test, there was no statistical difference between the groups $(\mathrm{p}=0.54)$.

Table $\mathbf{l}$ - Characterization of both groups based on the urinary incontinence diagnosis

\begin{tabular}{lcc}
\hline & Group MF & Group M \\
\hline Stress urinary incontinence & $72,7 \%(24)$ & $62,5 \%(20)$ \\
Overactive bladder & $15,1 \%(5)$ & $25 \%(8)$ \\
Mixed & $12,2 \%(4)$ & $12,5 \%(4)$ \\
Total & $100 \%(33)$ & $100 \%(32)$ \\
\hline
\end{tabular}

Tables 2 and 3 show the characterization of both groups based on patients' previous gestational data. One can notice that there was no significant differences regarding these variables between the groups.

Table 3 shows the comparison regarding sexual and urinary complaints and surgeries. One can notice the homogeneity between the groups regarding all parameters except sexual complaints, which was significantly more evident in the group who underwent physical therapy treatment.
Table 2 - Characterization of the number of pregnancies and obstetric background

\begin{tabular}{lccc}
\hline & Group MF & Group M & $\begin{array}{c}\text { Significance } \\
\text { level }\end{array}$ \\
\hline Pregnancy average & $4,8 \pm 2,8$ & $5,4 \pm 2,8$ & 0,42 \\
Vaginal delivery & $3,9 \pm 2,2$ & $4,3 \pm 2,6$ & 0,47 \\
Cesarean delivery & $1 \pm 0,74$ & $1,1 \pm 0,3$ & 0,69 \\
\hline
\end{tabular}

Table 3 - Characterization regarding sexual complaint and previous surgery

\begin{tabular}{lllc}
\hline & Group MF & Group M & Chi-square \\
\hline Sexual complaint & $57,50 \%(19)$ & $28,1 \%(9)$ & 0,02 \\
Ul previous surgery & $27,20 \%(9)$ & $15,62 \%(5)$ & 0,27 \\
\hline
\end{tabular}

Table 4 shows the percentage of women who were medically discharged and underwent surgery. One can notice that there was a higher frequency of cure and lower frequency of surgeries among women who underwent physical therapy treatment.

Table 5 shows data collected in the physical therapy treatment (group FM). The physical therapy treatment varied from 4 to 15 sessions $(8.7 \pm 3.4)$.

\section{Discussion}

According to Aldrigui et al. (38), the prevalence of UI in women increases with age, and according to Lacima et al. (39), UI affects from $10-30 \%$ of 50 to 64 year old women. The average age of volunteers taking part in this study was $50.51 \pm 10.63$, and corresponded to the climacteric period representing a predisposing factor for UI due to the reduction of estrogen and the significant density of estrogen receptors in the urethra and in the bladder neck. Based on a population survey performed in the city of Campinas, Guarisi et al. (40) observed that 35\% of climacteric women had SUI. Due to demographic changes in population, post-menopausal women will comprise a large portion of population in a near future. These women lead active lives, working, traveling, practicing sports and physical activities, and urinary dysfunction represents a significant and substantial impairment in their quality of life and daily activities (DA) $(41,42)$. 
Table 4 - Frequency of medical discharge and surgery in both groups.

\begin{tabular}{|c|c|c|c|c|c|}
\hline & \multicolumn{2}{|c|}{ Group MF } & \multicolumn{2}{|c|}{ Group M } & \multirow[b]{2}{*}{ Chi-square } \\
\hline & Yes & No & Yes & No & \\
\hline Medical discharge & $60,60 \%$ (20) & $39,40 \%$ (13) & $18,75 \%(6)$ & $78,78 \%$ (26) & 0,0005 \\
\hline Surgery & $30,30 \%(10)$ & $69,70 \%$ (23) & $81,2 \%$ (26) & $18,18 \%(6)$ & 0,00004 \\
\hline
\end{tabular}

Table 5 - Parameters assessed after the physical therapy treatment.

\begin{tabular}{ll}
\hline Parameters assessed & \\
\hline Gain of strength in the pelvic floor & $60,6 \%(20)$ \\
Decreased urinary frequency & $27,3 \%(9)$ \\
Decrease/no nocturia & $45,5 \%(15)$ \\
\hline
\end{tabular}

Usually the Literature $(4,9,42-44)$ considers SUI to be the more prevalent type of incontinence among women, varying between $12 \%$ and $56 \%$. However, most studies have their diagnosis based on clinical complaints. According to Table 1, there was higher prevalence of SUI in both groups. The factors related to dysfunctions in the pelvic floor are obesity, chronic bronchitis, vaginal births, multiparity, age, and changes in collagen (44). One can notice the high prevalence of pregnancy and vaginal births among the volunteers (Table 2), which can be one of the causes for the SUI, as according to Haphpeykar et al. (45) pregnancy and natural births are predisposing factors for the occurrence of SUI. Studies point out that women developing postpartum SUI are likely to develop it again within a twelve-year period $(46,47)$.

Sexual complaints occurred in both groups; however, they were more present in group MF (Table 3). According to Kaiser et al. (48), organic, psychosocial and situational changes may influence women's sexuality. The occurrence of diseases affecting genital or pelvic organs caused by aging, vaginal atrophy, decreased pelvic floor tropism, decreased lubrication and prior surgeries also decrease sexual desire (49).

Both groups had patients who had previously undergone surgeries to correct UI and in face of the persistence of its symptoms sought medical care again. The surgical correction is a costly process that can bring other symptoms and reduce one's activities, requiring rest. In addition, it can also cause complications and morbidity and may not always satisfactorily cure UI. According to reports from relapsing patients, surgery would only be considered when all conservative options have already been performed with no success or when patients refuse undergoing clinical treatment (50). Currently, physiotherapy is considered a first-line treatment for UI providing beneficial results for being conservative, minimally invasive, having low rate of side effects, in addition to its low cost (51). The Pelvic Floor Assessment Group of the International Continence Society (ICS) published an article stating that urgency, frequency, OB and SUI are symptoms of dysfunctions in the pelvic floor muscles and that its treatment should be performed together with the bladder retraining by a qualified Physiotherapist (52).

By the physical therapy treatment, it was possible to prevent surgery in $60 \%$ of cases (Table 4 ) using resources such as perennial exercise, biofeedback, vaginal cones, electro stimulation and bladder retraining according to the clinical complaints and results from the urodynamic study. The lower percentage of surgery in women from group MF shows that there are other treatment options that should be taken into account and made available to patients with UI. Results found on gain of strength, decreased urinary frequency and nocturia show the effectiveness of the physical therapy treatment (Table 5).

Studies point out that perennial exercise (53), whether isolated or together with EE (54), is effective in reducing urinary loss and retraining the proprioception of the urogenital area. In a test using ES, Herrmann et al. (51) observed that $77.2 \%$ patients did not have any losses when exerting by the therapy completion. Thus, one can conclude that ES is one useful therapeutic alternative for women with SUI. Capelini (55) observed that the learning provided by biofeedback, its training and the maintenance of exercises bring good results by reducing urinary loss from about 8.1 to 0.4 a day. García-Giralda et 
al. (56) observed the effectiveness of the mixed UI therapy using medications to reduce overactive bladder together with a pelvic floor rehabilitation program. The use of ES can improve symptoms (33, 57,58 ) up to $77 \%$ and may provide a $40 \%$ reduction in costs if performed instead of surgery.

Regardless of the technique employed, we found (Tables 5 and 6) a high success rate in this treatment, which provided data increasing the reliability of this therapy. It also showed that we must rethink about the physical and psychological conditions, which expose patients when priority is given to the surgery.

Despite all the encouraging data provided by this research, there is still much to do for urogynecologycal physiotherapy, as making patients aware of the importance of early treatment, and addressing the lack of motivation and adherence to the treatment as it does not produce immediate results. For it being a weekly treatment, many women quit it at the beginning, even before noticing any improvement in symptoms. The disclosure of and encouragement to this treatment option is essential to objectively improve the patients' quality of life. One can also notice the need for early intervention before symptoms become evident and troublesome to the patient, by making women aware of the pelvic floor function and of the importance of daily performing perennial exercise.

This study also shows the need for new studies comparing and proving which physiotherapy methods are the most efficient for each urinary incontinence type.

\section{Conclusions}

We therefore conclude that the use of physiotherapy techniques in women with urinary incontinence is an efficient way to decrease the symptoms and the number of surgeries required.

\section{References}

1. Bushnell DM, Martin ML, Summers KH, Svihra J, Lionis C, Patrick DL. Quality of life of women with urinary incontinence: Cross-cultural performance of 15 language versions of the I-QOL. Qual Life Res. 2005; 14(8):1901-13.
2. Johnson T, Ouslander J. The shifting impact of UI. J Am Geriatr Soc. 2001;49(7):998-9.

3. Zahariou AG, Karamouti MV, Papaioannou PD. Pelvic floor muscle training improves sexual function of women with stress urinary incontinence. Int Urogynecol J Pelvic Floor Dysfunct. 2008;19(3): 401-6.

4. Oh SJ, Ku H, Hong SK, Soo WK, Paick JS, Son H. Factors influencing self-perceived disease severity in women with stress urinary incontinence combined with or without urge incontinence. Neurourol Urodyn. 2005; 24(4):341-7.

5. Klausner AP, Vapnek JM. Urinary incontinence in the geriatric population. Mt Sinai J Med. 2003;70(1): 54-61.

6. Homma Y, Koyama N. Minimal clinically important change in urinary incontinence detected by a quality of life assessment tool in overactive bladder syndrome with urge incontinence. Neurourol Urodyn. 2006;25(3):228-35.

7. Margalith I, Gillon G, Gordon D. Urinary incontinence in women under 65: Quality of life, stress related to incontinence and patterns of seeking health care. Qual Life Res. 2004;13(8):1381-90.

8. Torres C, Ciocon JO, Galindo D, Ciocon DG. Clinical approach to urinary incontinence: A comparision between internist and geriatricians. Int Urol Nephrol. 2001;33(3):549-52.

9. Coyne KS, Zhou Z, Thompson C, Versi E. The impact on health-related quality of life of stress, urge and mixed urinary incontinence. BJU Int. 2003;92(7): 731-5.

10. Jamison MG, Weidner AC, Romero AA, Amundsen CL. Lack of psychological resilience: an important correlate for urinary incontinence. Int Urogynecol J Pelvic Floor Dysfunct. 2007;18(10):1127-32.

11. Amarenco G, Amould B, Carita P, Haab F, Labat JJ, Richard F. European Psychometric Validation of the CONTILIFE: A Quality of Life Qustionnaire for Urinary Incontinence. Eur Urol. 2003;43(4):391-404.

12. Hannestad YS, Rortveit G, Sandvik H, Hunskaar S. A communit-based epidemiological survey of female urinary incontinence: The Norwegian EPICONT Study. J Clin Epidemiol. 2000;53(11):1150-7. 
13. Brown JS, Posner S. Urge incontinence: new healthrelated quality of life measures. J Am Geriatr Soc. 1999;47(8):980-8.

14. Huang AJ, Brown JS, Kanaya AM, Creasman JM, Ragins AI, Van Den Eeden SK, et al. Quality of life impact and treatment of urinary incontinence in ethnically diverse older women. Arch Intern Med. 2006; 166(18):2000-6.

15. Wagg A, Potter J, Peel P, Irwin P, Lowe D, Pearson M. National audit of continence care of older people: management of urinary incontinence. Age Aging. 2008; 37(1):39-44.

16. Frank C, Brooks P. Practice tips. Bedside cystometry. Can Fam Physician. 2000;46:559-60.

17. Monz B, Pons ME, Hampel C, Hunskaar S, Quali D, Samsioe G, et al. Patient-reported impact of urinary incontinence-results from treatment seeking women in 14 european countries. Maturitas. 2005; 52(Suppl 2):S24-34.

18. Ghoniem G, Stanford E, Kenton C, Achtari C, Goldberg $\mathrm{R}$, Mascarenhas T. et al. Evaluation and outcome measures in the treatment of female urinary stress incontinence: International Urogynecological Association (IUGA) guidelines for research and clinical practice. Int Urogynecol J Pelvic Floor Dysfunct. 2008;19(1):5-33.

19. Woodman PJ, Misko CA, Fischer JR. The use of shortform quality of life questionnaire to measure the impact of Imipramine on women with urge incontinence. Int Urogynecol J Pelvic Floor Dysfunct. 2001; 12(5):312-5.

20. Shamliyan TA, Kane RL, Wyman J, Wilt TJ. Systematic review: randomized, controlled trials of nonsurgical treatments for urinary incontinence in women. Ann Intern Med. 2008;148(6):459-73.

21. Aboseif SR, Kim DH, Rieder JM, Rhee EY, Menefee SA, Kaswick JR, et al. Sacral neuromodulation: cost considerations and clinical benefits. Urology. 2007; 70(6):1069-73.

22. Petri E. Urologic trauma in gynaecological surgery: diagnosis and management. Curr Opin Obstet Gynecol. 1999;11(5):495-8.

23. Aslan E, Komurcu N, Beji NK, Yalcin O. Bladder training and kegel exercises for women with urinary complaints living in a rest home. Gerontology. 2008; 54(4):224-31.
24. Sampselle CM, Miller JM, Mims BL, Delancey JO, Ashton-Miller JA, Antonakos CL. Effect of pelvic floor muscle exercise on transient incontinence during pregnancy and after birth. Obstet Gynecol. 1998;91(3):406-12.

25. Santos PF, Oliveira E, Zanetti MR, Arruda RM, Sartori M, Castro R, et al. Eletroestimulação funcional do assoalho pélvico versus terapia com os cones vaginais para o tratamento de incontinência urinária de esforço. Rev Bras Ginecol Obstet. 2009;31(9):447-52.

26. Goermeley EA. Biofeedback and behavioral therapy for the management of female incontinence. Urol Clin North Am. 2002;29(3):551-7.

27. Berghmans LCM, Hendriks HJM, de Bie RA, van Waalmijk ESC, Bo K, van Kerrebroeck PHEV. Conservative treatment of urge urinary incontinence in women: a systematic review of randomized clinical trials. BJU Int. 2000;85(3):254-63.

28. Aukee $\mathrm{P}$, Immonen $\mathrm{P}$, Penttinen J, Jaippala $\mathrm{P}$, Auraksinen O. Increase in pelvic floor muscle activity after 12 weeks training a randomized prospective pilot study. Urology. 2002;60(6):1020-3.

29. Morkved S, Bo K, Fjortft T. Effect of adding biofeedback to pelvic floor muscle training to treatment. Obstet Gynecol. 2002;100(4):730-9.

30. Aksac B, Aki S, Karan A, Yalcin O, Isikoglu M, Eskiyunt N. Biofeedback and pelvis floor exercises for the rehabilitation of urinary stress incontinence. Ginecol Obstet Invest. 2003;56(1):23-7.

31. Vankerrbroeur PE. The role of electrical stimulation avoinding dysfunction. Eur Urol. 1998;34(suppl 1): 27-30.

32. Van der Pal F, van Balken MR, Heesakkers JP, Debruyne FM, Bemelmans BL. Percutaneous tibial nerve stimulation in the treatment of refractory overactive bladder syndrome: is maintenance treatment necessary? BJU Int. 2006;97(3):547-50.

33. Van Balken MR, Vandoninck V, Gisolf KH, Vergunst H, Lambertus A, Debruyne FJ, et al. Posterior Tibial Nerve Stimulation as Neuromodulative Treatment of Lower Urinary Tract Dysfunction 2001. J Urol. 2001; 166(3):914-8.

34. Okada N, Igowa Y, Nishizawa A. Functional electrical stimulation for detrusor instability. Int Urogynecol J Pelvic Floor Dysfunct. 1999;10(5):329-35. 
35. Carramão SS, Pacetta $\mathrm{AM}$, Carramão $\mathrm{S}$, Barros $\mathrm{AD}$, Mantesse JC. Avaliação da eletroestimulação na terapêutica da incontinência urinária de esforço feminina. Rev Ginecol Obstet. 2003;14(4):166-9.

36. Wang AC, Wang YY, Chen MC. Single-blind, randomized trial of pelvic floor muscle training, biofedback-assisted pelvic floor muscle training, and electrical stimulation in the management of overactive bladder. Urology. 2004;63(1):61-7.

37. Burgio, KL. Current perspectives on management of urgency using bladder and behavioral training. J Am Acad Nurse Pract. 2004;16(Suppl10):4-7.

38. Aldrigui JM. Alterações sistêmicas no climatério. Rev Bras Med. 2002;59:16-21.

39. Lacima G, Pera M, Valls-Solé J, González-Argenté X, Puig-Clota M, Espuma M. Findings in females with combined fecal and urinary incontinence: a prospective study. Dis Colon Rectum. 2006;49(3):353-9.

40. Guarisi T, Pinto Neto AM, Osis MJ, Pedro AO, Paiva LP, Faúndes A. Incontinência urinária entre mulheres climatéricas brasileiras: inquérito domiciliar. Rev Saúde Pública. 2001;35(5):428-535.

41. Wakamatsu MM. What affects bladder function more: menopause or age? Menopause. 2003;10(3):191-92.

42. Krause MP, Albert SM, Elsangedy HM, Krinski K, Goss FL, da Silva SG. Urinary incontinence and waist circumference in older women. Age Ageing. 2010; 39(1):69-73.

43. Dugan E, Cohen SJ, Robinson D, Anderson R, Preisser J, Suggs $P$, et al. The quality of life of older adults with urinary incontinence: determining generic and condition-specific predictors. Qual Life Res. 1998; $7(4): 337-44$.

44. Goode PS, Burgio KL, Locher JL, Roth DL, Umlauf MG, Richter HE, et al. Effect of behavioral training with or without pelvic floor electrical stimulation on stress incontinence in woman, a randomized controlled trial. JAMA. 2003;16(3):345-52.

45. Ricther HE, Burgio KL, Brubaker L, Nygaard IE, Ye W, Weidner A, et al. Continence pessary compared with behavioral therapy or combined therapy for stress incontinence: a randomized controlled trial. Obstet Gynecol 2010;115(3):609-17.
46. Haphpeykar SH, Mozayeni P, Young A, Fine PM. Stress urinary incontinence and counseling and practice of pelvic floor exercises postpartum in low-income Hispanic women. Int Urogynecol J Pelvic Floor Dysfunct. 2008;19(3):361-5.

47. Altman D, Ekstrom A, Gustafsson C, Lopez A, Falconer C, Zetterstrom J. Risk of urinary incontinence after childbirth: a 10-year prospective cohort study. Obstet Gynecol. 2006;108(4):873-8.

48. Viktrup L, Rortiveit G, Lose G. Risk of stress urinary incontinence twelve years after the first pregnancy and delivery. Obstet Gynecol. 2006;108(2): 248-54.

49. Kaiser FE. Sexual function and the older women. Clin Geriatr Med. 2003;19(3):463-72.

50. Lamb SE, Pepper J, Lall R, Jorstad-Stein EC, Clark MD, Hill L, et al. Group treatments for sensitive health care problems: a randomized controlled trial of group versus individual physiotherapy sessions for female urinary incontinence. BMC Womens Health. 2009;9:26.

51. $\mathrm{B} \emptyset \mathrm{K}$. Is there still a place for physiotherapy in the treatment of female incontinence? EAU Update Series. 2003;1(3):145-53.

52. Herrmann V, Potrick BA, Palma PR, Zanettini CL, Marques A, Rodrigues WJ. Eletroestimulação transvaginal do assoalho pélvico no tratamento da incontinência urinária de esforço - avaliação clínica e ultra-sonográfica. Rev Assoc Méd Bras. 2003;49(4): 401-5.

53. Kafri R, Shames J, Raz M, Katz-Leurer M. Rehabilitation versus drug therapy for urge urinary incontinence: long-term outcomes. Int Urogynecol J. 2008;19:47-52.

54. Berghmans LC, Hendrics HJ, Bo K, Hay AY, Smith EJ, Bie RH, et al. Conservative treatment of stress urinary incontinence in women, a systematic review of randomized clinical trials. Br J Urol. 1998; 82(2):181-91.

55. Amaro JL. Tratamento clínico da incontinência urinária feminina: eletroestimulação endovaginal e exercícios perineais. São Paulo: Faculdade de Medicina, Universidade Estadual Julio de Mesquita; 2000. 
56. Capelini MVMA. Tratamento da incontinência urinária de esforço com biofeedback: análise objetiva e impacto sobre a qualidade de vida [dissertação]. Campinas: Universidade Estadual de Campinas, Faculdade de Ciências Médicas; 2005.

57. García-Giralda RL, Guirao SL, Casas AI, Alfaro GJV, Sánchez PG, Guirao EL. Working with urinary incontinence in primary health care: satisfaction, sexuality and therapeutic compliance. Arch Esp Urol. 2007; $60(6): 625-32$.
58. Eriksen BC, Eiknes SH. Long term electrostimulation of the pelvic floor: primary therapy in female stress incontinence. Urol Int. 1989;44(2):40-5.

59. McAchran S, Daneshgari F. Sacral neuromodulation in the older woman. Clin Obstet Gynecol. 2007;50(3): 735-44.

Received: 02/07/2011

Recebido: 07/02/2011

Approved: 03/19/2011

Aprovado: 19/03/2011 